\title{
EXCHANGE RATE REGIME PROPOSAL FOR EMERGING COUNTRIES: A KEYNESIAN APPROACH*
}

\author{
Fernando Ferrari-Filho $^{* *}$ \\ Luiz Fernando de Paula ${ }^{* * *}$
}

\begin{abstract}
This paper presents, in the light of Keynesian theory and taking in account the emerging economies reality in nowadays global world, an exchange rate regime proposal for emerging countries with the capability to mitigate their external vulnerability and fragility and their dependence on foreign capital, and thus making possible the implementation of domestic economic policies that would permit macroeconomic stabilization - understood, following Keynes, as being the combination of price stability and full employment. For this purpose the paper revisits Keynes' proposals with regard to both exchange rate policy and capital inflows, with a view to showing how they contribute to maintaining full employment, develops a Post Keynesian view on financial globalization and the behavior of exchange rate, and finally presents a strategy for an exchange rate regime with capital controls for emerging countries.
\end{abstract}

Key words: Exchange rate regime proposal, capital controls, Keynesian theory, emerging countries.

JEL Classification: E12 and F33.

\section{Introduction}

The exchange rate regime that mainstream economists and international financial agencies, such as the International Monetary Fund (IMF), usually consider ideal for emerging countries is one with a largely unregulated capitals market, where capital mobility is absolutely unrestricted, and a perfectly flexible exchange rate (IMF, 2002). Under such a regime, domestic financial assets (securities) are regarded as perfect substitutes for international securities, and thus effective monetary policy is defined by parity between domestic and international interest rates, i.e. monetary expansion brings down domestic interest rates to levels below the international rate, leading to capital flight and consequent exchange rate devaluation, whose beneficial effects on current transactions

\footnotetext{
* The authors thank Philip Arestis for his comments on a previous version of the paper. All remaining errors are the authors' responsibility.

${ }^{* *}$ Full Professor of Economics, Rio Grande do Sul Federal University and CNPq Researcher. E-mail: ferrari@ufrgs.br and website http://www.ppge.ufrgs.br/ferrari.

${ }^{* * *}$ Associate Professor at the University of the State of the Rio de Janeiro and CNPq Researcher. E-mail: luizfpaula@terra.com.br and website: http://www.paginas.terra.com.br/educacao/luizfpaula.
} 
come to generate an expansion in aggregate demand, which raises domestic interest rates until equilibrium is re-established in the balance of payments; symmetrical effects are produced by restrictive monetary policy.

Set against this, the need to permit the emerging countries to pursue contracyclical fiscal and, more importantly, monetary policies (which, incidentally are fundamental to assuring their sustainable economic growth and harmonious social development) has reinforced the opinion of Keynesian economists and some policymakers that what is needed is to introduce capital management techniques and an exchange rate regime that prevents excessive exchange rate fluctuations, in order to achieve macroeconomic stability, understood, following Keynes (1936/1964: Chapter 24), as being the combination of price stability and full employment.

In recent years, the debate over exchange rate regimes (floating vs. managed) and maintaining or relaxing capital controls in emerging countries has once again become the center of attention, mainly following developments from exchange rate and financial crises in Mexico (1994-95), East Asia (1997), Russia (1998), Brazil (1998-99) and Argentina (2001-02) ${ }^{1}$. Emphasizing this argument, according to Stiglitz (2002), financial liberalization and capital mobility in the 1990s were the center of most of the currency crises in the world economy.

The main outcome of this debate is that implementing a free-floating exchange rate regime and capital account mobility, even when backed by responsible or credible economic policy - in line with Washington Consensus prescriptions ${ }^{2}-$, leaves emerging countries prone to the humors and short-term logic of capital accumulation. The conventional argument on the difficulties facing such countries is to attribute the volatility

\footnotetext{
${ }^{1}$ These exchange rate and financial crises yielded a consensus among academics and policymakers as to the need to restructure the international monetary system as an indispensable condition for the world economy, and particularly the emerging economies, to see a return to periods of expansion and economic prosperity. While there is a consensus that the international monetary system needs restructuring, the same cannot yet be said with regard to the mechanisms proposed to mitigate and/or put an end to instability in world exchange and financial markets. On this point, Eichengreen (1999, Chapters 6 and 7), Eatwell and Taylor (2000), Davidson (1994, Chapter 16, and 2002, Chapter 14) and Isard (2005, Chapters 7 and 8) offer a summary of the main options for restructuring the international monetary system.

${ }^{2}$ The neoliberal measures advocated for emerging countries by the Washington Consensus are as follows: (i) reduction or elimination of tariff barriers; (ii) free capital mobility, whether for foreign investment or for convertible currency transactions; (iii) fiscal discipline; (iv) tax reform; (v) financial deregulation; and (vi) privatizations.
} 
of foreign financing to the irresponsible economic policies they adopt (Caramazza and Aziz, 1998) ${ }^{3}$. The Keynesian view, meanwhile, regards floating exchange rate and high capital mobility as a destabilizing combination of factors that intensify exchange rate crises in emerging countries. Grabel (2003a), for instance, argues that the capital account liberalization and neo-liberal financial integration have brought some risks (currency, fragility, contagion, and sovereignty) to emerging countries.

Looking at the GDP performance of some emerging countries, such as the BRICs countries (Brazil, Russia, China and India) ${ }^{4}$, from 2000 to 2006, one can see that economic performance has differed among these countries: the annual average growth rate in Brazil was $3.1 \%$, in Russia was $6.6 \%$, in India was $6.4 \%$ and in China was $9.5 \%{ }^{5}$. Ferrari Filho and Paula (2006) show that the economic performance of BRICs countries in the 2000s is the result, at least partially, of the exchange rate regime, capital account convertibility and fiscal and monetary regimes adopted in each country. According to authors, "Russia, India and China, administrating their exchange rate regimes with restricted capital account convertibility, are cases of more or less successful macroeconomic policy management (...) [while] the more clearly liberal economic policy strategies adopted in the Brazilian economy (...) have not managed to assure the country sustainable growth” (Ibid.: 219).

Considering the idea above, a question addresses: What is the appropriate exchange rate regime and capital account convertibility for emerging countries that, in conformity with fiscal and monetary policies, achieves stable and sustainable economic growth?

To answer this question, the purpose of this article is to present, in the light of Keynesian theory and Keynes' ideas on exchange rate policy and capital mobility, an exchange rate regime proposal for emerging countries with the capability to mitigate their external vulnerability and fragility and their dependence on foreign capital, and thus making possible the implementation of domestic macroeconomic policies that would lead

\footnotetext{
${ }^{3}$ It is important to add that the conventional theory argues that a responsible economic policy is based on flexible exchange rate, capital mobility and inflation targeting regime.

${ }^{4}$ BRICs countries is an expression created by Goldman Sachs. The acronym BRIC comprises of the initials of the four important developing countries: Brazil, Russia, India, and China. According to the Goldman Sachs, in a report of 2001, the combined GDP of BRICs countries would be larger than the total GDP of the United States, Japan, Germany, France, Italy, and United Kingdom by 2050.

${ }^{5}$ These average growth rates were calculated by the author based on figures of IPEA (2007) and IMF (2007).
} 
to high levels of output and employment. In an open economy, adopting an alternative exchange rate regime and limiting capital flows can be necessary but not a sufficient condition to assure sustained economic growth in emerging countries; indeed, it should be part of a set of a coordinated macroeconomic policy (such as exchange rate policy, monetary policy and fiscal policy) oriented to stimulate and create a favorable environment to economic growth.

The main hypothesis developed in this paper is that a managed exchange rate and capital controls can play a key role in a macroeconomic policy oriented to achieve macroeconomic stabilization in emerging countries. On the evidence available (see, for example, Arestis, Ferrari-Filho and Paula, 2007, for relevant evidence in the case of Brazil; see also Angeriz, Arestis and Chakravarty, 2007) current arrangements of inflation and flexible exchange rate do not seem to work.

To that end, the paper is divided into three sections, in addition to this introduction. The next section explores Keynes' proposals, specially the International Clearing Union (ICU), with regard to both exchange rate policy and capital inflows, with a view to showing how they contribute to maintaining full employment. Section 3 develops a Post Keynesian view on financial globalization and the behavior of exchange rate. Section 4 presents a brief discussion of alternative exchange rate regimes and capital account mobility, followed by a strategy for an exchange rate regime with capital controls for emerging countries. Finally, a summary and some conclusions are offered.

\section{Keynes' proposals on exchange rate policy and capital mobility}

In The General Theory of Employment, Interest and Money (GT), Keynes shows that in monetary economics, fluctuations in effective demand and level of employment occur because, in a world where the future is uncertain and unknown, economic agents prefer to withdraw currency, and consequently their decisions to spend, whether on consumption or investment, are postponed. In other words, agents withhold currency as a kind of safeguard against the uncertainty entailed by their precarious knowledge about expected yields from their production plans.

Given that monetary economies do not necessarily converge to a position of full 
employment equilibrium ${ }^{6}$, extra-market interventions, such as control and regulation, are fundamental to "containing the immanent tendencies to disintegration inherent to the market economy" (Carvalho and Sicsú, 2006: 15) and thus creating the conditions that would offset the problems created by the circumstances under which economic agents make decisions. As we know, Keynesian policies is related to the implementation of economic policies that intend to increase aggregate demand in order to create a stable environment (more safety and with less uncertainty of actual possibilities) that stimulate entrepreneurs to make new investments. According to Carvalho (1997: 40),

"the ideal macroeconomic policy proposed by Keynes would in way inflate aggregate demand, expanding the economy like a balloon, leaving to private agents the decisions as to how the available resources would be employed (...). Boosting aggregate demand reduces both risks and so it should raise demand prices of that kind of asset with respect of money”.

While market intervention is necessary in closed economies, there is even more call for regulation and control at the international level, where trade and financial transactions involve a variety of currencies and, therefore, uncertainty is far greater.

With reference to the above idea, all Keynes’ proposals related to the international monetary system aimed at creating an international market maker that would be able to maintain full employment and price stability. To achieve such results, besides some adequate macroeconomic policies and institutional reforms, Keynes dedicated special attention to the monetary reform. According to him, the creation of an international liquidity currency was a fundamental condition to (i) assure the adequate elasticity of money supply to expanding the demand for investment and affect the global aggregate demand and (ii) bring in the funds necessary and sufficient for the process of short-term balance of payments adjustment, thus galvanizing aggregate demand globally. Thus, in order for economic agents' contractual decisions on spending to be taken in a less uncertain and unpredictable context, enabling effective demand to expand at the world level, it was

\footnotetext{
${ }^{6}$ It should be emphasized that, according to Keynes' The General Theory of Employment, Interest and Money (GT), unemployment is an equilibrium position.
} 
indispensable to restructure the international monetary system on the basis of an international market maker able to perform the functions set out above.

This is the direction taken by Davidson (1994, 2002), who builds on a taxonomy of his own, where the monetary dynamics among open economies may be of two types: unionized monetary system (UMS) or non-unionized monetary system (NUMS), to present a proposal for reform of the international monetary system called the International Money Clearing Union (IMCU). The idea consists in showing that Keynes' proposals for restructuring the international monetary system, and more specifically for creating an international reserve currency managed by an international market maker, converge to a system with the characteristics of a UMS, that is: a relatively fixed exchange rates in relation to the international monetary standard; monetary contracts expressed in the international reserve currency; and a monetary policy designed to assure more flexible (elastic) international liquidity. Increasing the IMCU's role in the world economy would be designed to prevent crises in effective demand, provide trigger mechanisms for automatically adjusting balance of payment disequilibrium, enable each nation to implement capital flow controls, and expand the amount of international liquidity (Davidson, 1994: 268).

In many of his writings, Keynes discussed and suggested schemes to reform the international monetary system as fundamental to assuring contracyclical fiscal and monetary policies with a view to obtain full employment and promote income distribution and to prevent changes in the liquidity preference schedule from having an impact upon the demand for investment and aggregate demand, respectively ${ }^{7}$. According to Carvalho (1997) and Ferrari Filho (2006), almost of the Keynesian proposals related to the international monetary system aimed at (i) substituting macroeconomic management for the blind acceptance of “invisible hand's market”, (ii) reducing private agent's uncertainties about the future in order to stimulate them on decision making related to production and investments, and (iii) creating a safe and flexible (more elastic) monetary system to expand the global effective demand and the level of employment.

\footnotetext{
${ }^{7}$ For instance, in A Treatise on Money (1930/1976), he outlined a proposal for the operation of a supranational central bank to maintain the stability of international price levels, in The Means to Prosperity (1933/1972), he presented an international agreement under fixed, but alterable, exchange rates, and in his proposal for an International Clearing Union (1944/1980), Keynes developed a scheme based on an international currency, bancor.
} 
Looking at the Keynes’ proposals to reform the international monetary system, it is the Keynes’s revolutionary analysis in the ICU that deserves special attention.

In his ICU, Keynes developed a proposal for restructuring the international monetary system in such a way that the world economy after World War II would assure conditions for full employment. Keynes argued that the discussions on restructuring the international monetary system should focus on setting up a world central bank (ICU), which would issue an international liquidity currency with a stable value standard. This Institution should be able to (i) set monetary and exchange rate rules, (ii) discipline trade policy, (iii) reorganize market dynamics in terms of the behavior of production, distribution and prices, (iv) regulate external investment, i.e. both venture and portfolio capital flows, and (v) signal rules for adjusting balance of payments (1944/1980: 233-234).

Concerning item (i), Keynes recommended that participating countries should adopt a regime of exchange rates that would be fixed, but adjustable, in relation to the international currency - bancor (Keynes, 1944/1980: 170). He argued that exchange rate fluctuations should be discrete - in intervals of at most $5.0 \%$ for both deficit and surplus countries - with a view to righting any temporary balance of payment disequilibrium. In Keynes’ words:

"We need an orderly and agreed method of determining the relative exchange values of national currency units, so that unilateral action and competitive exchange depreciations are prevented (...). The proposal is to establish a Currency Union, here designated an International Clearing Union, based on international bank money, called (let us say) bancor, fixed (but not unalterably) in terms of gold and accepted as the equivalent of gold” (Ibid.: 168-170).

Items (iv) and (v) of the ICU (above) are the conditions by which, according to Keynes (1944/1980: 176), “[t]he plan aims at the substitution of an expansionist, in place of a contractionist, pressure on world trade”.

As regards the capital flow controls, Keynes argued that:

"control of capital movements, both inward and outward, should be a permanent feature of the post-war system (...). The advocacy of a control of capital movements must not be taken to mean that the era of 
international investment should be brought to an end. On the contrary, the system contemplated should greatly facilitate the restoration of international credit for loan purposes (...). The object (...) is to have a means of distinguishing - (a) Between movements of floating funds and genuine new investment for developing countries (...) and (b) Between movements, which will help to maintain equilibrium, from surplus countries to deficiency countries, and speculative movements or flights out of deficiency countries or from one surplus country to another" (Ibid.: 185-187).

Keynes regarded capital controls as essential to preserving the flexibility of monetary policy to expand the demand for investment and, as a result, the aggregate demand and the level of employment. In his words, "the whole management of the domestic economy depends upon being free to have the appropriate rate of interest without reference to the rates prevailing elsewhere in the world" (Ibid.:149).

Keynes' idea concerned with capital controls began to be developed in the end of the 1920s, during the period he was policy advice at the Macmillan Committee - this Committee was created to present alternative proposals to England's departure from the golden standard and to solve the British unemployment. Keynes' efforts (writings and speeches) in this Committee were related to, among others, the effect of tariffs and national protectionist trade policies, the effects of unrestricted foreign investment and the possibility of controlling capital flows ${ }^{8}$.

As regards the idea that the costs of balance of payment adjustments should be distributed among the two groups of countries (deficit and surplus), Keynes opposed the gold standard approach to the monetary system, where the whole onus of external adjustment fell to the deficiency countries. He argued that:

"[i]t should be much easier, and surely more satisfactory for all of us, to enter into a general and collective responsibility, applying to all countries alike, that a country finding itself in a creditor position against the rest of the world as whole should enter into an arrangement no to allow this credit balance to exercise a contractionist pressure

\footnotetext{
${ }^{8}$ For the Keynes’ activities during the Macmillan Committee, see Keynes (1981).
} 
against world economy and, by repercussion, against the economy of the creditor country itself” (Ibid.: 178).

In summary, from a brief examination of Keynes' ICU proposal and considering the Keynes' thinking in the 1930s related to exchange rate regime and capital controls, three points stand out clearly: firstly, Keynes felt that exchange rate stability was fundamental to assuring price stability; secondly, in general, he recommended the adoption of a fixed, but adjustable, exchange rate regime to reduce the private agents` uncertainties; and, finally, he argued that a regime of fixed-but-adjustable exchange rates could be adopted both in a world of very open capital account (during the gold standard period) and in a world where capital mobility was restricted (the period between the Wars). In other words, Keynesian analysis regards more or less managed exchange rate regimes and capital controls as serving the purposes of macroeconomic stability, understood as the combination of controlled inflation and sustainable economic growth.

\section{A Post Keynesian view on exchange rate and global financial markets}

As it is well known, Post Keynesian approach stress the importance of nonprobabilistic uncertainty in order to understand the modus operandis of capitalistic economies in a global environment. Post Keynesian economists reject the hypothesis of market efficiency to explain the behavior of financial markets (Glickman, 1994; Davidson, 2002: Chapter 2). In an uncertain world, in which fundamentals do not provide a reliable guide to the future, as the informational basis related to human decision about the wealth accumulation is incomplete, the future forecasting about the price of financial assets are always subject to disappointments. Keynes and Post Keynesians reject the belief that some

observed economic phenomena are the outcome of any stochastic process, because for some occurrences, agents do not possess adequate information to construct future probabilities. The intrinsic value of the given asset, related to the values derived from discount rate related to the expected returns of assets, do not exist, as the discount rate varies according to the risk evaluation that can suddenly change in response to the facts, and, for this reason, cannot be known. In other words, intrinsic value or fundamentals of the assets prices is not calculable in an environment under Knight-Keynes uncertainty (Glickman, 1994). 
Speculation is essentially a subjective activity of forecasting the psychology of the market (Keynes, 1936/1964: Chapter 12). As volatility is a consequence of speculation, markets must be organized in order to limit price fluctuations that include continuous assets selling orders. This must be done by the establishment of access rules to the participants of the financial market, and mainly by the presence of a powerful market maker. Only these rules are able to inhibit great speculation effects.

Concerning the operation of the global financial markets, the starting point of Post Keynesian analysis is that in the post-Bretton Woods world the combination of volatile exchange rates and financial liberalization has increased a great deal the international capital movements. However, in contrast to the conventional view of financial globalization - that stress the possible benefits of financial integration related to the more efficient international capital allocation, improvement in the macroeconomic policies due to the competitive pressures of globalization, development of domestic financial system due to better financial regulation, etc. (Prasad, Rogoff, Wei and Kose, 2003) - Post Keynesian view states that the increasing capital mobility is more unstable than stable, as it increases the likehood of financial/currency crises and at the same time it results hard to manage economic policies ${ }^{9}$. Financial globalization increases the opportunities for investment finance, but at the same time it has been a source of big economic instability with effects on real variables, such as output and employment. Under the action of global players, in a more liberalized and integrated financial market, the operation of the financial markets has become a sort of big, global casino.

Post Keynesian economists and also other Keynesians of other theoretical approach $^{10}$ show that market liberalization and the rise of new financial instruments, as derivatives, increased the possibility of speculative operations in global financial markets ${ }^{11}$. In contrast with closed financial markets of yesterday, capital flows can have disruptive action on countries, damaging the autonomy of domestic macroeconomic policies, and even

\footnotetext{
${ }^{9}$ An interesting evaluation of the costs and benefits of globalization is done by Eatwell and Taylor (2000, Chapter 2).

${ }^{10}$ For a criticism on financial liberalization, see Tobin (1978) and Stiglitz (2000).

${ }^{11}$ For instance, Davidson (1997: 671-672) states that "in today's global economy any news event that fund managers even suspect that others will interpret as a whiff of currency weakness can quickly become a conflagration spread along the information highway. This results in lemming-like behavior that can be self-reinforcing and self-justifying”.
} 
generate speculative attacks on domestic currencies. As Eichengreen, Tobin and Wyplosz (1995: 164) state, "volatility in exchange rates and interest rates induced by speculation and capital flows could have real economic consequences devastating for particular sectors and whole economies”.

One example of such view is the determination of exchange rate, that, under the conditions of capital mobility, is increasingly determined by portfolio decisions of international investors, more related to a short-run view. Capital flows has been frequently a predominant force in foreign exchange markets, mainly in the case of emerging economies with thin financial markets, so that exchange rate behavior has been far too volatile for their only determinants to have been fundamental in origin (Harvey, 2003). Portfolio decisions are dependent from the changes in the market sentiment, that is investors' portfolio expectations. Such expectations are modeled using a combination of Post Keynesian conventional tools - such as the convention that economic agents consider the average opinion of the market when they make their own expectations - and other factors of psychological nature. According to Harvey (Ibid.: 133),

"the picture that emerges is not one of a market characterized by stability, efficiency and optimality (...), but of an institution where agents' imperfectly considered actions create currency prices. Those actions may be marked by stability for long periods (...) as agents rely on convention to anchor to stable levels or rates of change; but because they are subject to availability and bandwagon effects they are apt to rapid revision in the face of salient events (even when those events may seem inconsequential to cooler hands)".

Post Keynesian call attention for the increasing instability of financial markets in the current phase of globalization. Financial instability and speculative attacks on domestic currency can not be seen as anomalies, but on the contrary they are expected, and possible outcomes that emerge from the operation of global financial markets in a non-ergodic system where there is no safeguarding framework act as an overall market maker. In other words, a specific institutional design of a financial market determines its potential as an environment where speculation can flourish (Alves Jr, Ferrari-Filho and Paula, 1999-2000). 
As a consequence of their understanding of the foreign exchange market and the operation of financial markets, the most common recommendation of Post Keynesian economists with respect to the organization of international economy is that flow of capital should somehow be controlled ${ }^{12}$. Financial activity engenders systemic risks important enough to justify domestic regulation and capital controls. Grabel (2003a: 333) argues that “[a] programme of crisis prevention in emerging economies necessitates the implementation of a complementary policies [for instance, capital controls, such as a Chilean model]”. In this connection, Tobin (1978) interestingly stated that the main macroeconomic problem related to integrated financial markets is not the choice of the appropriate exchange rate regime but the excessive short-run capital mobility that reduces the autonomy of national governments to pursue domestic objectives with respect to employment, output and inflation. In Tobin's words, “the mobility of financial capital limits viable differences among national interest rates and thus severely restricts the ability of central banks and governments to pursue monetary and fiscal policies appropriate to their internal economies" (Ibid.: 154) ${ }^{13}$.

In other words, free portfolio capital flows (mainly in emerging countries) may interfere with ability to put in place policies oriented to domestic purposes, as they frequently generate a high interest rate-bias ${ }^{14}$, higher exchange rate volatility, and a limit for the use of active fiscal policies, due to the need to generate fiscal surplus in order to compensate the effects of a tight monetary policy on public debt. Under these conditions,

\footnotetext{
${ }^{12}$ According to Grabel (1996: 1764), a "developing country government that seeks to attract and maintain portfolio investment inflows may be severely constrained in the ex ante sense: the construction of an appropriate investment climate requires the adoption of a fairly restrictive set of policies. In addition to the en ante constraint on policy autonomy, there is also the possibility of an ex post constraint. This may obtain if, in the advent of capital flight or financial or currency crises, the government is compelled to adopt measures aimed at reversing the outflow of portfolio investment”.

${ }^{13}$ In a regime of fully open capital account, interest rates by arbitrage can be reduced to a level equal to the one dictated by uncovered interest rate parity; i.e. international interest rates plus the risk premium required for foreign investors to buy domestic assets plus the expected rate depreciation of domestic currency.

${ }^{14}$ High interest rate-bias in emerging countries is related to the use of interest rate to mitigate movements of exchange rate devaluation due to the "fear of floating" behavior of monetary authorities, and the uses of interest rates in countries that adopt inflation targeting regime, mainly in case of countries that had recent history of high inflation where pass-through of exchange rate devaluation to domestic inflation is higher than other countries where agents do not have inflationary memory. See, for instance, Eichengreen (2002).
} 
additional uncertainty makes private investments even lower and people's desire to hold cash and liquid assets even higher, resulting in a lack of effective demand that does not expand the level of employment.

Therefore, capital controls can be also seen as a way to ensure that national authorities will be able to implement expansionary policies aiming at reaching and maintaining full employment without fear of inducing capital flight. Palley (1998), for instance, argues in favor of the adoption of a floating exchange rate regime, but that at the same time capital mobility should be limited by use of some sort of capital controls, such as a tax on capital inflows and/or the implementation of minimum term for permanence of capital flows (Chilean-style capital controls). This would permit that emerging countries improve their ability to achieve a more autonomous economic policy, and at the same time maintaining a more stable exchange rate - inspired in Keynes' ideas but at the same time taking in account the new environment of financial globalization. We focus these issues in the next section.

\section{Managed floating exchange regime and capital controls: a strategy for the emerging countries}

Since the Bretton Woods international monetary system collapsed in the early 1970s, the process of globalization, characterized by increasing international mobility of capital and financial deregulation, has substantially altered the dynamics of the world economy. Moreover, in the absence of macroeconomic policies to stimulate economic growth and limit the destabilizing movements of capital flows, international capital mobility has created serious monetary and exchange problems for the world economy, especially for the emerging countries ${ }^{15}$. According to Grabel (2003b: 251), “[e]conomies with internationally integrated, liquid, liberalized financial systems are inherently crisis prone"

Going in this direction, one important discussion in the literature about macroeconomic issues in emerging countries is which exchange rate regime is more appropriate for these countries. On one hand, according to the "bipolar" view intermediary

\footnotetext{
${ }^{15}$ The adoption of floating exchange rate regimes and free capital mobility by emerging countries has destabilized their currencies and leveraged exchange crises there, because their external fragility and vulnerability and dependence on foreign capital make them inherently unstable.
} 
regimes - that involve all sorts of intermediary exchange rate regimes, that is between freely floating regime and fixed exchange rate regime - are less appropriate for economies with substantial involvement in international capital markets. The main argument is that such exchange rate regimes make countries more vulnerable to speculative attacks (Fischer, 2001). On the other hand, the view called "fear of floating"' points out that many emerging countries that adopt flexible exchange rate regime in practice seek to limit exchange rate movements. Such resistance to floating arises from their low policy and institutional credibility and high degree of pass-through of exchange rate changes into domestic prices, among other factors (Calvo and Reihart, 2002). Other reasons to why monetary authorities avoid exchange rate movements are related to the effects of excessive exchange rate volatility (mainly devaluation) on the outstanding foreign currency debts of banks and the corporate sectors with unhedged foreign currency liabilities. In addition, exchange rate fluctuations may generate uncertainties that could impede trade. For instance, prolonged real appreciation associated with large capital inflows can adversely affect export competitiveness and investment in the external sector.

Indeed, some economists (Edwards and Savastano, 2000; Edison, Levine, Ricci and Slok, 2002, Fischer, 1998; Obstfeld and Rogoff, 1995) argue that a flexible exchange rate regime with capital account convertibility is fundamental for emerging countries to absorb the capital inflow and respond to the changing productive capacity in these economies ${ }^{16}$. According to them, for an emerging country open to a substantial volume of international capital flows, a flexible exchange rate (i) reduces the sources of external vulnerability, and (ii) increases the efficiency of monetary policy to control the inflation rate; at the same time, financial liberalization (i) allocates efficiently savings (domestic and foreign), (ii) disciplines macroeconomic policies, and, consequently, (iii) improves the economic growth performance $^{17}$.

Eichengreen and Leblang (2002) and Rodrik (1998) show that it is difficult to establish a robust relationship between financial liberalization and economic growth

\footnotetext{
${ }^{16}$ According to the conventional (neoclassical) theory, capital should flow out of industrialized countries, where capital is abundant, into emerging countries where capital is scarce and, as a result, the rate of return to capital should be greater.

${ }^{17}$ Some economists argue that the discipline of fiscal and monetary policies are more important than the choice of exchange rate regime. See, for instance, Calvo and Mishkin (2003).
} 
performance for developed and, especially, emerging countries ${ }^{18}$. Interestingly, Einchengreen and Legland (2002: 2) suggest that developed countries first developed their domestic financial market, followed by restricted capital account convertibility and after they liberalized their capital account: "the impact of capital account liberalization is more likely to be positive when the domestic financial system is smooth and stable. It is more likely to be negative when domestic and international financial markets are subject to crises”. So, it is likely that the causality between financial liberalization and economic growth is reverse: countries that have a robust economic growth can choose to take part of the financial integration, even if it does not contribute directly for a greater economic growth.

One could argue that the adoption of a freely flexible exchange regime by emerging countries could isolate these countries from speculative attacks on domestic currency as government has no commitment with any level of exchange rate. Besides, floating exchange regime could increase the autonomy of monetary policy, overcoming the "impossible trinity" that says that a country cannot have at the same time capital account convertibility, fixed exchange rate regime and monetary policy autonomy in order to achieve domestic objectives. However, floating exchange regime frequently works in the real world differently from what is supposed in the textbooks. According to Grenville (2000), fundamentals cannot explain the behavior of exchange rate over a short/medium term horizon, that is exchange rate have at times exhibited long-lived swings with no apparent changes in fundamentals significant enough to justify them. The problems related to the exchange rate volatility are greater for emerging countries, as they have: (i) no long historical experience of market-determined exchange rate; (ii) few stabilizers speculators acting in the exchange market, that is there has been a lack of players willing take contrarian foreign exchange positions in emerging countries; and (iii) much larger and volatile capital flows, in relation to the size of their capital markets and economies more generally. According to Ho and McCauley's data (2003), despite of the rapid growth in activity during the 1990s, foreign exchange markets in most emerging countries continue to

${ }^{18}$ Empirical evidence of capital account liberalisation upon economic performance is ambiguous while their links with financial crises are quite evident. Economists of IMF (Prasad, Rogoff, Wei and Kose, 2003: 3) resume the empirical findings of the literature: "a systematic examination of the evidence suggests that is difficult to establish a robust causal relationship between the degree of financial integration and output growth performance”. 
be relatively small and less liquidity than their counterparts in the industrial world. This suggests that emerging foreign exchange markets are more prone to one-sided bets and instability, because they are thin and subject to a high degree of uncertainty and information asymmetries (Moreno, 2005: 10).

Flexibility in the operation of floating exchange regimes can be helpful in absorbing the capital inflow, in buffering external shocks, and responding to the changing productive capacity of emerging economies; it can also inhibit some short-term flows, by serving as a constant reminder that exchange rate volatility can outweigh the interest rate advantage of foreign currency borrowings (Grenville, 2000: 59). Some sort of managed floating exchange rates regime can be useful if the objective of the central bank is to reduce the exchange rate volatility and also influence somehow the real exchange rate for international trade purposes. Central bank intervenes in foreign exchange markets to achieve a variety of macroeconomic objectives, such as controlling inflation, maintaining external competitiveness and/or maintaining financial stability. Differently from a pegged exchange rate, authorities' interventions to limit exchange rate movements may not target a certain level of the exchange rate, allowing nominal exchange rate to float in order to disincentive speculative capital flows but may influence its path. The preservation of a competitive and stable real exchange rate can be use as an intermediate target of macroeconomic policies oriented to employment and growth objectives. According to Frenkel (2006: 579):

“a competitive RER [real exchange rate] involves the distortion of domestic relative prices in favour of tradable activities against nontradable activities: the combination of higher protection for local activities that compete with imports with a higher competitiveness for export activities. Consequently, the RER affects the employment growth rate in the long run due to its influence on the output growth rate, through its incentive on investment in tradable activities that accelerates productivity growth and generates positive externalities in other sectors".

In order to enhance the possibility of a successful management of exchange rate regime in emerging markets can be necessary some measures to reduce the volatility of capital flows and the likehood of speculation attack on domestic currency. One possibility 
is the use of official intervention in the foreign exchange market, that may exert direct influence on nominal exchange rate as it alters the relative supply of domestic and foreign currency assets. On one hand, the countries' ability to resist currency depreciation is limited by its stock of foreign exchange reserves and its access to potential credit lines. Reserve accumulation can be seen as an insurance against future negative shocks and speculation against domestic currency, as emerging economies have limited access to international capital market. On the other hand, the ability to avoid currency appreciation may require the use of sterilized intervention. The accumulation of reserves requires some sort of financing due to the excess of foreign currency reserves over domestic currency in circulation. The central bank can finance this gap by issuing domestic monetary liabilities. If central banks have a target for the short-term rate, then they can attempt to offset increases in bank reserves selling domestic assets or issuing their own securities (Mohanty and Turner, 2006).

There are some concerns about the prolonged use of foreign exchange intervention to resist currency appreciation. One concern is related to the fact that a large portfolio currency asset exposes the central bank to potential valuation losses for currency appreciation. A second concern is related to the carrying costs of reserves, that are determined by the difference between the return on domestic assets and foreign assets ${ }^{19}$. Finally, continuous reserve accumulation might at some point raise problems for the central bank in controlling monetary growth. The assessment of the recent experience of exchange reserve accumulation in emerging countries shows evidences that such countries have so far been successful in sterilizing reserve operations (Mohanty and Scatigna, 2004; Mohanty and Turner, 2006). On one hand, carrying costs have been low or even negative in an important number of countries (including China, India and South Korea), although they have been high in some countries (Brazil and Indonesia). On the other hand, many central banks may have used reserve accumulation to expand the monetary base to deliberately ease monetary policy in an environment of low inflation and large excess capacity. Due to the effectiveness of official foreign exchange intervention and low inflation environment,

${ }^{19}$ Cost of sterilisation is calculated as the spread between the domestic and the USD one-year Treasury bill rate, applied to the total outstanding stock of foreign exchange reserves in domestic currency. 
real exchange rate have not risen significantly (or even fallen) in many countries with large and persistent current account surplus.

Another possibility to enhance the management of exchange rate regime (that is not excluding with official intervention) in emerging countries is the use "capital management techniques" that includes “capital controls", that is norms that manage volume, composition, and/or allocation of international private capital flows, and/or "prudential domestic financial regulations”, that refer to policies, such as capital-adequacy standards, reporting requirements, or restrictions on the ability and terms under which domestic financial institutions can provide to certain types of projects ${ }^{20}$ (Epstein, Grabel and Jomo, 2003: 6-7).

Capital controls can be used for different sometimes related objectives, such as (i) to reduce the vulnerability of a country to financial crises, including capital flight during any currency crisis, (ii) to drive a wedge between onshore and offshore interest rates in order to provide monetary authorities with some policy autonomy at least in the short-run, and (iii) to maintain some short-term stability of nominal exchange rate and to reduce exchange rate pressures derived from excessive capital inflows. For this purpose capital controls can be used to change the composition and maturity structure of flows (towards longer maturity flows) and to enhance monetary authorities’ ability to act in the exchange foreign market.

Although the effectiveness of capital controls are very controversial, evidence suggests that the macroeconomic benefits of capital management techniques can outweigh the microeconomic costs as show some recent experiences. Magud and Reihart (2006) review more than 30 papers that evaluated capital controls either on inflows or outflows around the world (the evaluation excludes countries with comprehensive capital controls, such as China and India), making use of a capital controls effectiveness index in order to standardize the results of the empirical studies. They conclude that "capital controls on inflows seem to make monetary policy more independent; alter the composition of capital flow; reduce real exchange rate pressures (although the evidence is more controversial)”, but "seem not to reduce the volume of net flows (and hence, the current account balance)", while "limiting private external borrowing in the 'good times' plays an important prudential

\footnotetext{
${ }^{20}$ Prudential controls can include: (i) to limit the opportunities for residents to borrow in foreign currency and to monitor them when they do, and (ii) to keep very tight constraints on banks' ability to have open foreign exchange positions or indirect exposure through foreign exchange loans.
} 
role because more often than not countries that are 'debt intolerant'” (Ibid.: 26-27). In the same connection Ho and McCauley (2003: 34) concludes that "recent experience has shown that capital controls, if properly designed and applied, can be helpful in protecting the economy against the desestabilising aspects of capital flows, supporting the implementation of other policies and even resolving certain types of policy dilemma”.

Summing up, taking in account the discussion developed in this section and in line with Keynes' proposals presented in the second section and the Post Keynesian view on globalization financial system showed in section 3, it is felt that managed floating exchange rate regime and imperfect capital mobility are more appropriate to emerging countries, because they make possible the adoption of contracyclical economic policies, fiscal and monetary, necessary to permit macroeconomic stabilization.

\section{Summary and Conclusions}

Since the collapse of the Bretton Woods system in the early 1970s, the increased international mobility of capital and financial liberalization - i.e. the globalization process has substantially altered the dynamic process of world economy. In other words, the globalization process has limited the actions of macroeconomic policies and national states to stimulate effective demand and, as consequence, increase the level of employment. Moreover, in the absence of government macroeconomic policies to stimulate economic growth and to limit the movements of capital flows, international speculative capital flows have created serious financial and exchange rate problems in the world economy, specially in the emerging countries ${ }^{21}$.

Globalization, in turn, tends by it very nature to disrupt not only domestic markets, but whole countries, especially emerging countries, by establishing a kind of extended financial casino. Keynes, in Chapter 12 of his GT, sees strong connections between the real and financial sectors of the economy. One such connection is the impact of speculative activities on production activities, and especially on investment. To quote a passage from

\footnotetext{
${ }^{21}$ It is important to add that, due to (i) the significant increase in the volume and speed of fund transfers on the international financial market, (ii) the blurring of boundaries between markets and (iii) greater integration among financial markets worldwide, the economic dynamics of those decades came to be known as the process of financial globalization. One consequence of this process is the tendency for a single world money and credit market to be established. In this regard, see Ferrari Filho and Paula (2004).
} 
GT in which Keynes identifies a connection between the real and financial sectors of the economy:

"the position is serious when enterprise becomes the bubble on a whirlpool of speculation. When the capital development of a country becomes a by-product of the activities of a casino, the job is likely to be ill-done” (Keynes, 1936/1964: 159).

This paper shows that - as recommended by Keynesian theory - in a context of financial globalization, i.e. greater economic interdependence and more intense intercountry capital flows, conditions must be created in order for national economic policies to be operated autonomously. On this point, in view of the lack of any institutional arrangement for international monetary cooperation to organize the world economy, emerging countries' response to financial globalization depends on their introducing (i) mechanisms to permit exchange rate management to assure domestic policy objectives and promote a more predictable environment for productive investment and productive activity in general and (ii) capital controls to preserve the independence of their economic, and especially monetary, policies.

To conclude, it is important to stress that managed exchange rate regimes and capital controls are not ends in themselves, but are means to achieving economic prosperity, full employment and more equitable income distribution among individuals and among countries. In this context, according to Davidson (1997: 672) "what is necessary is to build permanent fireproofing rules and structures that prevent 'beauty contest' induced currency fires. Crisis prevention rather than crisis rescues must be the primary long-term objective". 


\section{References}

Alves Jr, A., Ferrari-Filho, F., and Paula, L.F. "The post Keynesian critique of conventional currency crisis models and Davidson's proposal to reform the international monetary system. Journal of Post Keynesian Economics, 22(2), Winter 1999-2000, 207-225.

Angeriz, P., Arestis, P., and Chakravarty, T. "Assessing the empirical evidence on inflation targeting and possible lessons for Brazil”. In: Arestis, P., and Saad-Filho, A. (eds.). Political Economy of Brazil. London: Routledge, 2007, 94-115.

Arestis, P., Ferrari-Filho, F., and Paula, L.F. "Inflation targeting in emerging countries: the case of Brazil”. In: Arestis, P., and Saad-Filho, A. (eds.). Political Economy of Brazil. London: Routledge, 2007, 116-140.

Calvo, G., and Mishkin, F. “The mirage of exchange rate regimes for emerging market countries”. Journal of Economic Perspectives, 17, 2003, 99-118.

Calvo, G., and Reinhart, C. "Fear of floating”. Quarterly Journal of Economics, CXVII (2), 2002, 379-408.

Caramazza, F., and Aziz, J. Fixed or flexible? Getting the Exchange Rate Right in the 1990s. Washington, DC: IMF, 1998.

Carvalho, F.C. “Economic policies for monetary economies”. Brazilian Journal of Political Economy, 17(4), 1997, 31-51

Carvalho, F.C., and Sicsú, J. “Controvérsia recentes sobre controles de capitais”. In: Ferrari Filho, F., and Sicsú, J. (orgs.). Câmbio e Controle de Capitais: avaliando a eficiência de modelos macroeconômicos. Rio de Janeiro, Campus-Elsevier, 2006, 128.

Davidson, P. Post Keynesian Macroeconomic Theory. Aldershot: Edward Elgar, 1994.

. "Are grains of sand in the wheels of international finance sufficient to do the job when boulders are often required?’. Economic Journal, 107 (442), May 1997, 671686.

. Financial Markets, Money and the Real World. Cheltenham: Edward Elgar, 2002.

Eatwell, J., and Taylor, L. Global Finance Risk: the Case of International Regulation. New York: New Press, 2000. 
Edison, H., Levine, R., Ricci, L., and Slok, T. “International financial integration and economic growth”. Journal of International Money and Finance, 21, 2002, 749776.

Edwards, S., and Savastano, M. "Exchange rate in emerging economies: what do we know? What do we need to know?”. In: Krueger, A. (ed.). Economic Policy Reform: The Second Stage. Chicago, University of Chicago Press, 2000, 453-510.

Eichengreen, B. Toward a New International Finance Architecture: a Practical Post Asia Agenda. Washington, DC: Institute for International Economics, 1999.

- Can emerging markets float? Should they inflation targeting?. Working Papers Series 36. Brasília, Banco Central do Brasil, February 2002.

Eichengreen, B., and Leblang, D. “Capital account liberalization and growth: was Mahathir right?”. NBER Working Paper Series 9247, December 2002.

Eichengreen, B., Tobin, J., and Wyplosz, C. "Two cases for sand in the wheels of international finance”. Economic Journal, 105 (428), January 1995, 162-172.

Epstein, G., Grabel, I., and Jomo, K.S. "Capital management techniques in developing countries”. Working Paper Series 56, Political Economy Research Institute, University of Massachusetts, 2003.

Ferrari Filho, F. Política comercial, taxa de câmbio e moeda internacional: uma análise a partir de Keynes. Porto Alegre: UFRGS, 2006

Ferrari Filho, F., and Paula, L.F. (orgs.). Globalização Financeira: Ensaios de Macroeconomia Aberta. Petrópolis: Vozes, 2004.

- "Regime cambial, conversibilidade da conta capital e performance econômica: a experiência recente de Brasil, Rússia, Índia e China”. In: Ferrari Filho, F, and Sicsú, J. (orgs.). Câmbio e Controle de capitais: avaliando a eficiência de modelos macroeconômicos. Rio de Janeiro: Campus-Elsevier, 2006, 184-221.

Fischer, S. "Capital-account liberalization and the role of the IMF”. Essays in International Finance, 207, 1998, 1-10.

. “Exchange rate regimes: is the bipolar view correct?”. Journal of Economic Perspectives, 15(2), 2001, 3-24. 
Frenkel, R. “An alternative to inflation targeting in Latin America: macroeconomic policies focused on employment”. Journal of Post Keynesian Economics, 28(4), 2006, 573591.

Glickman, M. "The concept of information, intractable uncertainty, and the current state of ‘efficient markets’ theory: a Post Keynesian view”. Journal of Post Keynesian Economics, 16(3), 1994, 325-349.

Grabel, I. "Marketing the Third World: the contradictions of portfolio investment in the global economy”. World Development, 24(11), 1996, 1761-1776.

. "Averting crisis? Assessing measures to manage financial integration in emerging economies”. Cambridge Journal of Economics, 27, n³, May, 2003a, 317-336

. "Predicting financial crisis in developing economies: astronomy or astrology?" Eastern Economic Journal, 29, Spring 2003b, 243-258

Grenville, S. “Exchange rate regime for emerging countries”. Reserve Bank of Australia Bulletin, November 2000.

Harvey, J. (2003). Exchange rates. In King, J.E. (ed). The Elgar Companion to Post Keynesian Economics. Cheltenham: Edward Elgar, 2003

Ho, C., and McCauley, R. "Living with flexible exchange rates: issues and recent experience in inflation targeting emerging market economies. BIS Working Paper 130, February 2003.

Instituto de Pesquisa Econômica Aplicada (IPEA). http://www.ipeadata.gov.br. Access in September 2007.

International Monetary Fund (IMF). World Economic Outlook, September 2002, http://www.imf.org.br. Access in September 2007.

World Economic Outlook, April 2007. http://www.imf.org. Access in September 2007.

Isard, P. Globalization and the International Financial System: What's Wrong and What Can Be Done. Cambridge: Cambridge University Press, 2005.

Keynes, J. M. The General Theory of Employment, Interest and Money. New York: HBJ Book, 1964.

. Essays in Persuasion. London: Macmillan, 1972 (The Collected Writings of John Maynard Keynes, vol. 9). 
A Treatise on Money. New York: AMS Press, 1976.

Activities 1940-1944: Shaping the Post-War World, the Clearing Union. London: Macmillan, 1980 (The Collected Writings of John Maynard Keynes, vol. 25, edited by Moggridge, D.).

. Activities 1929-131: Rethinking employment and unemployment policies. London: Macmillan, 1981 (The Collected Writings of John Maynard Keynes, vol. 20, edited by Moggridge, D.)

Magud, N, and Reinhart, C. “Capital controls: an evaluation”. NBER Working Paper 11973, January 2006.

Mohanty, M., and Scatigna, M. "Has globalization reduced monetary policy independence?” BIS Papers 23, 2004.

Mohanty, M., and Turner, P. "Foreign exchange reserves in emerging countries”. BIS Quarterly Review 24, 2006, 39-42.

Moreno, R. “Motives for intervention”. BIS Papers 24, May 2005.

Obstfeld, M., and Rogoff, K. “The mirage of fixed exchange rates”. Journal of Economic Perspectives, 9, Fall 1995, 73-96.

Oreiro, J.L., and Paula, L.F. “Strategy for economic growth in Brazil: a Post Keynesian approach”. In Arestis, P., Baddeley, M., and McCombie, J. (orgs.). Economic Growth: new directions in theory and policy. Cheltenham: Edward Elgar, 2007.

Palley, T. Plenty of Nothing: the downsizing of the American dream and the case for structural Keynesianism. Princeton: Princeton University Press, 1998.

Prasad, E., Rogoff, K., Wei, S., and Kose, M. "Effects of financial globalization on development countries: some empirical evidence”, 2003, available in http://www.imf.org. Access in October, 2007.

Rodrik, D. "Who needs capital-account convertibility?”. Essays in International Finance, 207, 1998, 55-65.

Stiglitz, J. “Capital market liberalization, economic growth, and instability”. World Development, 28(6), 2000, 1075-1086.

Stiglitz, J. Globalization and Its Discontents. New York: WW Norton, 2002.

Tobin, J. “A proposal for international monetary reform”. Eastern Economic Journal, 4(3/4), 1978, 153-59. 